\title{
Asset Base Community Development in Community Development of Bold Indonesian Group of Reds Football Supporters Regional Medan (Medan Regional Bigreds) At Merdeka Village, District of Medan Baru, Medan
}

\author{
Husni Thamrin, Agus Suriadi \\ Faculty of Social and Political Science, University of Sumatera Utara \\ Email: pungkut@gmail.com
}

\begin{abstract}
Community service activities is one of the obligations that should be carried out by each lecturer at the College as one aspect of Tri Darma College. The activity by each service team is entitled as Asset Base Community Development In Community Development of Bold Indonesian Community Group Of Reds Football Supporters Regional (Regional BIGREDS Terrain) in Merdeka Village, District of Medan Baru. The issues to be resolved from community service are: the strengthening of groups or communities through empowerment of a community asset, the creation of the entrepreneurship for each members of football community BIGREDS Regional Medan and the economic empoweringfor the groups and football communitiesin BIGREDS Regional field through training, entrepreneurial skills, and business provision.The mentoring by USU Service Team through football community empowerment in Regional BIGREDS will be expected to create employment opportunities and a strong network of fellow members of the football community in BIGREDS Regional Medan. Through this service, the targets to be achieved are 1). Empowerment of community assets of BIGREDS Regionals. 2). The creation of entrepreneurship spirit in each member who participated in the training. 3). The creation of a business form that can be utilizedby the members of the football community Regional BIGREDS in improving the economic income. The Service programs have managed to guide the group until they can make a T-shirt-screen-printing production.
\end{abstract}

Keywords: Community, Empowerment, Soccer, Asset Base Community

\section{PRELIMINARY}

Community football fans are one of the communities can be empowered. This is because during these football fans only serve as a forum gathering of people who love one football club both nationally and internationally. Behaviors that are not well reported by the media seeing also good television, print about the behavior of football fans, among others as another brawl with fellow football when his favorite club lose the match.

These behaviors arise because of the action group or a fraction of the members of the community so that it becomes anarchy such as vandalizing public property, Tauran, and actions violating the rules and others. But not a few football fans who do social actions such as providing donations to the poor, poor, orphans, and other social action. This is the initial capital to see a community asset crate group of fraternity, a sense of community, social awareness, empathy. Which can be used in community empowerment through the development of a community asset base.

If supporter football community can be directed toward better through the empowerment of the asset base of the community, it will create that community members have the power; the future is expected to coordinate the behavior of the community. Empowerment of community members can be done by utilizing community assets owned by the group and develop the creativity of two members of the group in the activities of economic empowerment as grow entrepreneur soul.

Along with the development of communication technology in the world, the development of football supporter also experienced a significant increase. Many football fans now have changed their status to become more institutionalized. It is characterized by the discovery of AD / ART (Statutes and Bylaws) organization. Through the standard rules that have been established organization is a group of supporters expected more controlled and organized. This is then glimpsed several large companies as a market that is very potential

One soccer fan community in the Indonesian city of Medan is Bold Reds Supporters' Group Of Regional Field which is the largest group of Liverpool fans in Indonesia. BIGREDS today has apresence in more 
than 48 cities/regions in Indonesia with the number of members reached 33567 people. BIGREDS in its field since 2006. Until 2017 period, Medan Regional BIGREDS already has 359 members.

On several occasions the discussion, we can see the huge potential market that is owned BIGREDS Regional Medan as a group of football supporters. In a production system merchandise, Regional BIGREDS field to this day still has to depend on the central BIGREDS production. In fact, if the production is done independently regionally will create new business opportunities for existing members inside. In AD / ART, stated that each regionalBIGREDS gave discretion to create merchandise by their respective regional idea. Not only that, but the central committee BIGREDS also required to promote regional merchandise that has passed quality control center BIGREDS.

The problem faced by these communities in the expected business development are precisely the activities carried less than utilizing spare time owned by its members. Another problem is the lack of communication that exists, not their patron in the organization up to thepoor management of the organization in this community.

Members of the community background, of course, vary, according to the regional coordinators of Medan Regional BIGREDS many members of this community who do not have a steady job. Also, some members of this community have the status of a fresh graduate, so he welcomes the development potential of these community members is needed to improve the productivity of the community and every individual involved in it. Seeing this, the activities that can be done to develop potential of this community is the Asset Base Community empowerment through training and education entrepreneurship.

Asset Base Community empowerment through training and education entrepreneurship is by doing activities such as training and seminars related to organizational management and product marketing. The products being manufactured are T-shirts associated with this community. Training of production and screen printing t-shirts that will be created by this community will involve members of the community who are registered as members of the Regional BIGREDS Medan.

\section{METHOD OF EXECUTION}

Method of community services are in the form of counseling in the form of lectures and discussions and followed by practice shirt screen printing followed by community members BIGREDS Regional Medan.

Stages of the activities undertaken include preparation of the material science related to the development of the asset base of the community, mapping the potential of the members of the reinforcement material from the early and most recently the Implementation of the practice of entrepreneurial activities and the development of the asset base of a community of fans Supporters Football Bold Indonesian Group Of Reds Supporters Regional Medan (BIGREDS Regional field) in the village of Medan Merdeka, district of Medan Baru

Scholarly preparation in the form of materials related to community empowerment through the development of a community asset base conducted on the subject of targeted community Bold Indonesian Football Supporters Group Of Reds Supporters carried out at Jalan Medan Regional Farmers Sei no.13 which is basecamp community Terrain Regional BIGREDS , This stage is the process of establishing an agreement between the teams dedication and Regional Bigreds field as the target of devotion. Activity was agreed on August 3 Bigreds Regional secretariat is housed in Medan. On this occasion Terrain, Regional Bigreds submit the names representing the Regional Bigreds Terrain in community service activities. The names of, among others; Dhaifan Asyari, John Nainggolan, Eka Prahardian, Fajar Kurniawan, and Christyan Pasaribu.

Mapping the potential of the asset base of communities Bold Indonesian Football Supporters Group Of Reds Supporters Terrain Regional (Regional BIGREDS Terrain) in the village of Merdeka, district of Medan Baru to do empowerment of communities/groups according to the potential of the group members. The goal is that members who participate in this event have the desire and passion that would allow them to maximize the potential of the member.

Strengthening early materials through training and skills entrepreneurship to community members Bold Indonesian Football Supporters Group Of Reds Supporters Regional Medan (Medan Regional BIGREDS) conducted by providing 
counseling and discussion with members involved in service activities. This activity is carried out in the form of motivational training of entrepreneurs in the form of exchange of experience with successful young entrepreneurs to increase youth entrepreneurial passion partners. The speakers invited are Walid Mustafa Sembiring who is director of CV. Sahara archipelago. He explains how his shirt business trip to be a success.

Implementation of the practice of entrepreneurial activities and the development of the asset base of a community of fans Supporters Football Bold Indonesian Group Of Reds Supporters Regional Medan (BIGREDS Regional Medan) is done by a whole series of shirt sales beginning with the purchase of a plain shirt, screen printing process to marketing which is entirely made directly by member community.

As an initial stage, given the devotion partners debriefing form of training design by using the software. Training software for creative design geared to improve the ability of business personnel in designing for printing paper design and screen design. Software prioritized for Rehearse is like Corel Draw and Adobe Photoshop for creative design. Design made starting from a simple design using one or two colors.

The next training is provided stencilmaking training. This stage begins by entering a design that has been prepared for screen printing which has been prepared to dry and become the main ingredient in the screen printing process.Furthermore, the partner is prepared to provide paint to be used according to need. Training went well; participants were enthusiastic about the training of screen printing. Many of those who claim to be more enthusiastic and motivated to immediately undertake the production of screen printing. Partners are now ready for t-shirt printing process. Shirt production carried out at both partners namely CV. SAHARA NUSANTARA. The second partner is a provider of equipment used in service activities.

The most important thing being the primary aspect of marketing is branding, for it is then accompanied by the partners to manufacture the brand used in their products. In this activity also agreed branding "TauKlenMedan" used a trademark T-shirt screen printing production resultswould be.

Publication of the product at the beginning of production will focus on the club's supporters of
Liverpool FC. To that end, the publication will utilize Bigreds website and various print and online media to optimize the marketing of products shirt. Looking at the market results not only Bigreds shirt production alone, then the publication is important to expand the network of existing markets.

The latter is the evaluation stages of implementation. Evaluation of the program, at this stage the team will conduct an evaluation related to the quality of production, financial management, active organization, and sales of production. Through the evaluation phase will illustrate the success or failure of the implementation of the program.

\section{RESULTS AND DISCUSSION}

Community service activities have increased the productivity of Medan Regional BIGREDS community. It can be seen from the enthusiastic members in participating in a series of activities to do. Members looked serious and diligent in all activities starting from counseling related to strengthening entrepreneurship training materials manufacture shirt screen printing.

The results of this activity are also felt directly for Regional BIGREDS community development field. Currently, the Regional BIGREDS community Terrain owns productive activities in their spare time owned by its members before it becomes a problem because the time you have wasted by unproductive things like ground coffee than fellow members.

Shirts that sale are quite got the attention of all members of BIGREDS well in Medan, and other cities were able to add cash held BIGREDS community to continue to grow given the increasing number of their members. It can be seen from the results in the first week of sales, which reached 70 pieces. Also, other perceived impact is this community can run for the better after getting understanding related to management of the organization given in this activity.

For community members who are directly involved in all these activities also felt the positive effects. The three members of this new skills that they can apply, skill in screen printing process that can be applied to a new establishment. 


\section{CONCLUSION}

The team has successfully established a dedicated production team shirt screen printing in cooperation with the Regional Bigreds Terrain as partners in service. Service activities performed community service team Institute for Research, and Community Service (LPPM) Field Service received a very good response from the target program. It can be seen from the enthusiasm of the participants dedication in following each stage of devotion. Service activities has made it ditahapan trademark determination and the production of $\mathrm{T}$ shirt screen printing.

Through this public service activities, community Terrain Regional BIGREDS managed to get an increase of various aspects of the organization. The first aspect is related community members pahamnya management organization so that the implementation of community activities can run better and leads to things that are more productive. The second aspect is the increase in cash held Terrain Regional BIGREDS community. The last and that the focus of these activities are community members who have skills that can be developed and used in support of life and meet their needs.

\section{REFERENCES}

Burgon \& Huffner. 2002. Human Communication. London: Sage Publication

Cathart, R.S., and Larry A. Samovar, 1974. Small Group Communication : A Reader. New York : Holt, Rinehart and Winston, Inc.

Chamala, R.S., 1995. Overview of Participative Action Approaches in Australian Land and Water Management. Dalam Chamala, S. and Keith, K. (eds), 1995.Participative Approaches for Landcare: Perspective, Policies, Program. Brisbane : Australian Academic Press.

Chambers, R. (1985). Rural development : putting the last first. London ; New York: Longman.

Effendi, Onong Uchjana 2003. Ilmu Komunikasi Teori dan Praktek. Bandung: PT. Remaja Rosdakarya.

Fajar, Marhaeni. 2009. Ilmu Komunikasi : Teori dan Praktek. Yogyakarta: Graha Ilmu.

Friedman, John, 1992. Empowerment The Politics of Alternative Development. Blackwell Publishers, Cambridge, USA.
Hikmat, H., 2004. Strategi Pemberdayaan Masyarakat. Penerbit Humoniora, Bandung.

Kartasasmita, Ginandjar, 1996. Pembangunan Untuk Rakyat- Memadukan Pertumbuhan dan Pemerataan. Penerbit PT. Pustaka CIDESINDO, Jakarta.

Khairuddin, 2000. Pembangunan Masyarakat., Tinjauan Aspek: Sosiologi, Ekonomi dan Perencanaan. Liberty, Yogyakarta.

Ife, J.W., 1995. Community Development: Creating Community Alternatives-vision, Analysiis and Practice. Melbourne : Longman.

Mulyana, Deddy. 2010. Ilmu Komunikasi Suatu Pengantar. Bandung: PT. Remaja Rosdakarya

Prijono, O.S. dan Pranarka, A.M.W., 1996. Pemberdayaan: Konsep, Kebijakan dan Implementasi. Centre for Strategic and International Studies, Jakarta.

Sears, David 0., Jonathan L Freedman \& L. Anne Peplau. 1985. Psikologi Sosial,. Diterjemahkan oleh Michael Adryanto. Jakarta.: Erlangga.

Sumodiningrat, G. (1999). Pemberdayaan Masyarakat dan Jaring Pengaman Sosial Jakarta: Gramedia.

Syahyuti, 2006. 30 Konsep Penting dalam Pembangunan Pedesaan dan Pertanian. Jakarta : Bina Rena Pariwara.

West, Richard\& Lynn H.Turner. 2009.Pengantar Teori Komunikasi: Analisis dan Apilkasi. Jakarta: Salemba Humanika. 